\title{
Practitioners' experiences of student supervision in the bachelor of social work degree
}

\author{
Shernaaz Carelse and Leticia Poggenpoel
}

\begin{abstract}
The developing and evolving social welfare system in South Africa coupled with inadequate human and material resources and high staff workloads, all impact on student learning in the Bachelor of Social Work (BSW) degree. This paper focuses on the challenges experienced by social work practitioners with regard to student supervision in the BSW. A qualitative case study design was used, in which the researcher purposively selected social work practitioners involved at third-year level teaching and learning in the BSW at a selected South African university. The findings point to challenges relating to limited agency resources, institutional-agency cooperation and students' personal challenges. These findings have implications for social work education and practice in South Africa as well as for continued professional development of social workers and agencies who offer student placements to universities.
\end{abstract}

\section{Introduction}

Similar to other professional social, human and health sciences programmes offered by higher education institutions the Bachelor of Social Work (BSW) degree involves a theory and a practice component. Professional development and facilitation of learning in higher education is achieved through practice-based learning when theory and practice are integrated (Oko, 2008; Morgan, 2006; Koh, 2002; Spouse, 2001). The integration process occurs when theory is consulted during the process of learning clinical skills (Morgan, 2006). Synergy between field experience and classroom learning is, therefore, vital. This synergy is the responsibility of academics and social workers employed at social services agencies that provide practice placements for BSW students.

Social workers who facilitate field supervision of BSW students at the social services agencies should be able to make connections (for the student) between classroom learning and fieldwork training (Knight, 2001). In so doing, the methods for fieldwork assessment will be appropriate and aligned to classroom learning. It is thus necessary for field supervisors to have in-depth knowledge of the curriculum content covered in the classroom. Similarly it is important for academics to know what students do in fieldwork placements. The practice component of the BSW involves learning outcomes for which students must complete learning tasks in the prescribed timeframe and standards prescribed by the 
university (Petersen, 2010; South African Qualifications Authority (SAQA), 2003). Collaboration with field supervisors in fieldwork placements is, therefore, essential in making learning happen. Race (2005) argues that collaboration should include all stakeholders (lecturers, tutors, field supervisors, course designers and students). In this way, students will take greater responsibility for their learning if policies are learner-centred (Race, 2005; Ramsden, 2003). Collaboration between academic staff and field supervisors has become vitally important in terms of designing curricula based on practice and discipline-specific needs. Academics then should plan with field supervisors and students how to create relevant and significant learning opportunities in practice (Petersen, 2010; Bozalek, 2009). In such collaboration academics and social work practitioners need to stay abreast of developments in the field of social work in order to address the gaps and challenges in student supervision, which if negated, could affect student learning.

In South Africa authentic learning environments for BSW students are constrained because of challenges relating to agency structures, scarce agency resources, and social workers' competence regarding student assessments in the BSW (Collins, 2012; Petersen, 2010). These challenges have implications for student learning in fieldwork placements and for the achievement of expected learning outcomes in the BSW (Collins, 2013). Students rely on supervision in their fieldwork placement to address their learning needs. Thus supervision is a complex process involving students' needs and the requirements of agencies, service users and professionals (Department of Social Development (DSD) and SACSSP, 2012; Walker, Crawford and Parker, 2008). This article describes some of these complexities by focusing on the challenges experienced by social workers who facilitate student supervision of third-year BSW students at a selected South African university.

\section{Literature review and problem statement}

In 2003 the South African Standards Generating Body (SGB) accepted the BSW qualification which is facilitated in an outcomes-based approach. South African higher education training institutions offering the BSW were required to implement the new BSW in 2007. Consequently, the previous, norm-based Bachelor of Arts in Social Work degree was replaced with the criterion-referenced BSW (Collins, 2012). Additionally in terms of the National Plan for Higher Education, learning programmes are to be structured in such a way that different components of a programme relate to each other meaningfully (Collins, 2012). Significant in this approach to education is a clear set of learning outcomes that encompass all components of the programme. This will also include defining conditions and opportunities for achieving learning outcomes. In this regard, the BSW has a field education component, the key goal of which is to apply theory (classroom knowledge) to fieldwork (clinical practice) (Petersen, 2010; Teigiser, 2009; SACSSP, 2003). Moreover, social work training requires discipline-specific knowledge and has statutory accountability to the SACSSP (Collins, 2012) as well as to the learning institution/university (Bozalek, 2009). Currently the criteria for the BSW in the South African context are in line with international standards for social work training (Lombard, Grobbelaar and Pruis, 2003). The responsibility of the academics is to make the learning outcomes explicit and to focus efforts on students embedding the knowledge of theory while the field supervisor should 
ensure that theory knowledge is integrated in fieldwork tasks by facilitating student supervision in the practice settings.

\section{Framework for social work supervision}

Supervision is a structured process used by the supervisors to review and reflect on their work. It relates to the continuous learning and performance of the supervisee (Kadushin, 1992). Social work supervision is characterised by a mutual, reciprocal and antidiscriminatory relationship between the supervisor and supervisee. The relationship is based on the theories, models and perspectives on supervision which are adopted by the social services agency. So, social work supervision is context-specific within the boundaries of the professional relationship. One of the role-players in such a professional relationship is the experienced social worker who has been authorised by the social service agency to supervise a social worker, student social worker, social auxiliary worker and student auxiliary worker. The supervisor is responsible for all the educational, supportive and administrative functions (of supervision) required for promoting competent and professional social work services to service users (DSD and SACSSP, 2012).

Social work supervision is generally practice-based and is a process in which learning is facilitated and occurs in a mutual relationship of shared responsibility between the supervisor and supervisee (Kadushin, 1992). The responsibility of supervisor and supervisee relates to mutual participation and accountability for learning and development of the supervisee as a professional practitioner. The supervisor, therefore, is the knowledgeable "other" who shares this knowledge with the supervisee. The aim of knowledge development is for the benefit of the client system (Engelbrecht, 2002; Kadushin and Harkness, 2002). Thus supervision is aimed at developing the supervisee's knowledge, skills and professional values (Engelbrecht, 2004; Botha, 2000) for the benefit of practice. Be this as it may, there is no single way of approaching supervision. There are various models for social work supervision which borrow from other disciplines such as psychology and psychopathology (Kadushin, Harkin, 2002).

There are generally six models for social work supervision (Botha, 2000; Kadushin, 1992; Doel and Shardlow, 1986) which will only be mentioned briefly, since a detailed analysis would go beyond the scope of the current paper. The first is the structural model which focuses on the relationship between the supervisor and the supervisee. The growthorientated model is focused on the social worker's personal and professional development while the organisational model focuses on the organisation's autonomy in terms of administrative responsibility of the social work supervisor. The theory model is centred on the theoretical frameworks, discourse, programmes and practice frameworks of the organisation. The holistic model is characterised by the relationship between theory, academic material and real-life experiences in the practice setting. The final model generally used is the developmental model which is centered around the application and mastering of skills and on self-awareness relating to these skills (Botha, 2000). 
In addition, there are three models specifically aimed at student supervision in social work (Engelbrecht, 2004; Engelbrecht, 2001). The first model, namely the role-system model, focuses on expectations, communication, contact, delivery and flexibility. The second, the integrated theory and practice model, is aimed at facilitating learning and reaching learning outcomes. The final model, which was developed by Shardlow and Doel (1996), is the competency-based model, and is essentially the outcomes of the first two. It is aimed at competency development of the student social worker. In terms of this model, outcome rather than process is emphasised (Engelbrecht, 2001). Furthermore, the competence perspective for supervision is aimed at enriching the educational process of supervision (Guttman, Eisikovits and Malucci, 1988). In this sense, competence means achieving tasks and goals that are predetermined by the supervisor and the student. Guttman et al. (1988) make reference to three components of competence, namely (1) capacities and skills, (2) motivation and (3) quality of the environment. Competence in terms of knowledge and skills in social work is the principal goal of the BSW curriculum in the South African context. It is essential that supervisors have the necessary knowledge and skills to plan and prepare students for practice, and create an environment that will provide opportunities for student learning. In essence this is the professional responsibility of the student supervisor as teacher in social work practice (Reyneke, 2010). Thus the knowledge base and competence of the student supervisor as teacher need to be sound in order to facilitate student supervision effectively.

There are strong correlations between the developmental model and the competency-based model, which are both appropriate models for student supervision because both emphasise learning and competencies of the supervisee through a process of distinct developmental stages. In line with this notion of competence and drawing on assertions by Kadushin (1992), the DSD and SACSSP (2012) developed a framework that outlines the roles, functions and accountability for supervision of practitioners, auxiliary social workers and student social workers. The framework relies on a developmental model in line with the developmental approach to social welfare in South Africa. The underlying assumption of this model is that the supervisee is continuously learning and developing in practice. Further developmental supervision is based on the unique process of acquiring competence as supervisees' needs differ from each other, and each stage of development requires an environment that will enhance and enable growth and competency (Walker et al., 2008). The objective of supervision in this model, therefore, is to identify growth and developmental needs to ensure good practice and service delivery to clients.

Linked to the aforementioned, there are specific responsibilities relating to the supervisor and the supervisee (Bradley, Engelbrecht and Höjer, 2010; Nzira and Williams, 2008; Botha, 2000; Hawkins and Shohet, 2000; Kadushin, 1992). These responsibilities are linked to the various models of supervision. Various writers (Botha, 2000; Hawkins and Shohet, 2000; Kadushin, 1992) concur that the supervisor should ensure a safe environment to lay out issues relating to practice knowledge, skills and professional values. The supervisor is further responsible for assisting with exploration and developing critical thinking skills of the supervisee. A key responsibility is to challenge unsafe and incompetent practice on the 
supervisee's part. Furthermore the supervisor shares appropriate experiences and skills with the supervisee. The supervisee on the other hand has the responsibility to develop selfawareness, identify practice issues and be open to receive feedback. The supervisee's responsibility is to monitor the effectiveness of supervision for his/her own development (Nzira and Williams, 2008; Botha, 2000; Hawkins and Shohet, 2000; Kadushin, 1992). This means that the process has various components because supervision does not occur in isolation as there are particular responsibilities and role expectations from and for the academics, supervisors and supervisees (in and between people in their environment). For student supervision to be effective there needs to be meaningful collaboration between academics, students and student supervisors, while serving vulnerable clients (Nzira and Williams, 2008).

The goal of the competency model and the developmental model of supervision is to develop the student's professional knowledge, skills and values in the execution of fieldwork tasks, while serving vulnerable communities. The role of the supervisor, therefore, is to align educational objectives with the individual developmental needs of the supervisee. The goal of supportive supervision is to boost the morale, enhance job satisfaction and increase the quality of work by the supervisee. The role of the supervisor is to be a resource and to provide an enabling environment in which the supervisee will feel supported and where productivity will be increased. Increased productivity will reduce job-related stress which, if unattended, may hamper productivity (DSD and SACSSP, 2012). The collaboration between academics and student supervisors is, therefore, essential in making learning happen and for addressing effective student learning.

There are several studies in the South African context related to student and academic experiences in teaching and learning in social work (Collins, 2012; Petersen, 2010; Dykes, 2009; Schenck, 2009; Earl, 2008). However, there is not much literature on student supervision with reference to field supervisors' experiences in the BSW in the South African context. In addition, the nature and scope of social issues globally has changed, and this change affects the nature of social work training generally. In the South African context in particular, changes relating to shifts in community needs, the developing and evolving social welfare system, limited organisational human and material resources and high staff workloads, all impact on and necessitate changes in social work teaching and learning (DSD and SACSSP, 2012; Petersen, 2010).

Against this backdrop, student supervision is in need of scrutiny by academics and practitioners who offer student placement in fieldwork settings. The aim of this study was, therefore, to explore and describe the challenges experienced by student supervisors relating student supervision in fieldwork placements. The research question was: What are $c h$ a l lenges experienced by field supervisors with regard to student supervision in the BSW degree? 


\section{Research approach and methodology}

A qualitative case study (Yin, 2003) was used, looking at the challenges experienced by student supervisors at a selected university in South Africa. An exploratory and descriptive design (Creswell, 2007) was used. Two focus group sessions (Fouché and Schurink, 2011) were conducted with eight social workers who facilitated student supervision. These were selected from eight agencies offering fieldwork placements to third-year social work students in the BSW programme. Participants were assured anonymity and were advised that they could withdraw at any stage of the research process. A semi-structured interview schedule was used for data collection focusing on the challenges experienced by social workers regarding student supervisors in the BSW. Thematic data analysis (De Vos, 2005; Creswell, 2009) was used, which emanated in five themes. Permission to conduct the study was granted by the Senate Committee, the Dean of Community and Health Science Faculty and the Head of the Social Work Department at the university where the study was conducted.

\section{Results and discussion}

\section{Field supervisors' experiences of challenges relating to student supervision}

The findings resulted from the data collected from eight field supervisors offering practice placements at non-governmental organisations to third-year social work students. Six themes emerged from the data analysis.

\section{Theme 1: Suitability of placements}

A fieldwork placement in social work training is regarded suitable if the theory framework taught at the university is followed by the organisation, and the supervisor has sound knowledge, skills and values to develop students as competent practitioners (Nzira and Williams, 2008). The discussion indicates that the theoretical orientation of most organisations and the knowledge base of some field supervisors do not match the expectations of the training institution.

Participants perceived that a number of agencies where students were placed were not familiar with the "new" theories that students are taught at university. The following quotes illustrate their general views:

“... many agencies don't work strength-based ... They still working ... old paradigm and its uh ... many of them are not working strength base ..."

"I think if you are placing students at a agency where they not working strength base ... you going to have students who don't know what they doing ..."

"So ... for future for any student make sure that they have at least started with strength base and that they partner with that organisation that have worked with these students."

Field supervisors were in agreement that a major challenge for the integration of theory and practice was the mismatch between the philosophies and theoretical knowledge taught at the university and that of the practice setting. This complicates the supervision of students in the field. Academics should plan with field supervisors how to create appropriate and significant learning opportunities in practice settings (Petersen, 2010; Bozalek, 2009). The 
implication is that if field supervisors are not familiar with postmodern theories taught in class, they will not be able to guide the student with the integration of theory and practice. It is for this reason that Nzira and Williams (2008) caution that fieldwork placements should be suited for academic development and that evaluation of such placement is crucial to determine placement effectiveness.

\section{Theme 2: Supervisor knowledge base}

Social workers globally share a common theoretical and knowledge base and in the South African context it is crucial that social workers and, therefore, student social workers are well grounded with practice knowledge, understanding and skills in a variety of settings (Simpson and Raniga, 2014).

Participants shared concerns about their own ability to supervise students. They said that they are challenged by the new theories because they are not familiar with the theories that students are taught. Furthermore they must constantly familiarise themselves with the new theories introduced by the academics and rely on students for the theory notes as these are not always provided by the social work department. Some participants said that they access literature on the theory approaches at their own cost to read up on the theories students are taught. The following quotes illustrate the general views:

"I think for me ... my greatest challenge is the theory [be]cause I've never done it." "The theories change every time. I also felt challenged in that way in that I wasn't on par with the new information ... the new assessment tools, the approaches and models."

"As an agency supervisor you have to read because you wonder will I be able to supervise this student properly ... in terms of getting not just the student's academic requirements but also fieldwork."

"It is unfair towards the students if we assess them using the same forms as the lecturers. We can give an overview of how they applied the theory but we are not aware of what they do in class."

In terms of the SACSSP code of ethics for education and training, only qualified and registered social workers may supervise social work students (SACSSP, 2003) and the assumption is that supervisors are well grounded in the theories, knowledge and skills required for supervision (Simpson and Raniga, 2014; DSD and SACSSP, 2012). This is aligned with the SACSSP code of conduct that social workers are to keep abreast with developments and research relating to the profession (SACSSP, 2003).

\section{Theme 3: Collaboration between academics and field supervisors}

Participants expressed the need for closer collaboration between the university/fieldwork coordinator and student supervisors to ensure that students are meeting academic requirements but also considering the agency realities. Participants said that they are not informed about what is being taught in the lectures. They expressed their desire to have knowledge about theory and what is happening in class to better assist the students in the application of theory. Their voices are summarised in the following quotes: 
"Somehow I would like to be more informed about what is happening in their class." "I have thought throughout the year if only if I had some copies of what they are doing in advance it would assist me. And I would have been able to assist them [students] better."

It can be concluded that participants often relied on students to guide them in terms of the theory that needed to be integrated in fieldwork practice. This was a dilemma because the students themselves struggled to understand the theories they had been taught. Field supervisors in this research did not feel adequately able to aid students' development because of the challenges relating to their own knowledge base. They relied on students to guide them in terms of the theory and programme details.

Challenges experienced by participants relating to insufficient collaboration between the social work department and the organisations clearly compromised the quality of supervision for integrating theory and practice. Participants also commented on some of the personal challenges that students experienced which influenced the quality of supervision and their commitment to their fieldwork assignments. For effective integration of theory and practice, there needs to be collaboration between training institutions and organisations where students are placed (Nzira and Williams, 2008), in other words, between academics who facilitate the coordination of fieldwork and field supervisors.

For fieldwork education to be effective, it is essential that all role players work collaboratively in the best interest of student academic progress while serving vulnerable clients. Student success depends largely on the collaboration between facilitators of learning (Simpson and Raniga, 2014). All the participants in this research have identified this as a challenge. The need to address this issue is a collective responsibility of all the role players. Referring to Weimer (2002), students will take greater responsibility for their learning if policies are learner-centred. By their own admission, field supervisors are also learners in this case. It can be concluded that students and field supervisors have not provided much input in the development of the fieldwork programme at this particular university.

\section{Theme 4: Emotional intelligence}

Emotions have often been considered as hampering rationality when in fact "reason and emotion are complementary ... states of awareness" (Butler, 2010:46). Participants mentioned that students seemed overwhelmed by some of the cases that were assigned to them. The following is what they had to say about students' engagement with clients:

"Students sometimes struggled to contain clients and deal with traumatic cases."

"The student seemed out of her depth with a particular case, where a ten-year-old was raped by a relative. "

"They lack experience of working in traumatic situations."

Participants felt that the students did not have the emotionally maturity for the type of cases that they engaged with. However, in terms of self-awareness, they could reflect on the 
experience which, therefore, acknowledges their feelings (challenges) as they realised the responsibility for responsiveness they should possess.

The facilitator (in this case the supervisor) expects, plans and deals with the human dimensions of teaching, which is of equal importance to mastering the subject or the design of facilitation resources and the teaching techniques. Therefore, debriefing students during supervision sessions by way of reflection is an important part of their academic development as well as developing emotional intelligence.

\section{Theme 5: Time management}

One of the critical cross-field outcomes of the BSW is the student's ability to manage his/her time effectively (SACSSP, 2003). Participants reported that students struggled to manage time effectively. This impacted on submission of reports and caused absenteeism and a general lack of commitment to the placement. Some participants had empathy with the students, believing that the students had genuine challenges in terms of time management with the overwhelming demands of their full academic programmes and deadlines. However, some participants said that the nature of tertiary education is that it is demanding and that some students use this "feeling of being overwhelmed" as an excuse not to produce their work.

"And then the reports, not the submission ... I received a whole lot on the last day of the placement. The excuse was always that there were problems with the computer. So I think she may have submitted on time to you but I struggled enormously to get the reports from them."

"I felt so sorry for these kids. If it was not the taxi's it was this or that they needed to get done. It is so anxiety provoking. So it is difficult. That I appreciate ..."

"They [the students] really stressed out. They are writing a test on Monday or Thursday and on Wednesday they are at the agency and they thinking of this and only half way finish. It's that emotional ... Sometimes they just well, confuse."

The issue of time management could possibly be linked to an overload as well as to the structure of the module and or the entire programme (third year of study). This relationship is relevant to the facilitators and developers of the programme. The issue of time management relates to the structure of the academic programme, specifically the purpose of assessment. In a programme of study where the curriculum is overloaded, it is natural that students would struggle to embed learning. Learning tasks in the fieldwork component of the BSW should be aligned to learning outcomes more realistically. In this way, students would be able to complete learning tasks in the prescribed timeframe, and adhere to standards expected by the university (Petersen, 2010).

\section{Recommendations}

Recommendations based on the conclusions of the findings are:

- Academics and practitioners should evaluate the suitability of the practice placement regularly and/or as the BSW curriculum changes. 
- Service level agreements between universities and field placement agencies should be explicit with regard to the BSW curriculum outcomes.

- Training for student supervisors offering fieldwork practice placement to BSW students should be offered by the university. This could be facilitated as part of continuous professional development which is a requirement of the SACSSP.

- Student supervisors should provide regular feedback to students which is specific to the students' specific learning needs and professional development.

- Universities in partnership with practitioners, SACSSP and DSD should become major collaborators in lobbying for the allocating of human and financial resources for BSW student supervision.

\section{Conclusion}

The research set out to explore and describe the challenges experienced by social workers who facilitate student supervision of third-year social work students from a selected South African university. All participants in the study expressed concerns about the relevance, co-operation and co-ordination of academic and fieldwork learning for student supervision. Student supervisors shared concerns that fieldwork placements do not always meet academic expectations, noting that there are not always qualified and/or experienced social workers available to supervise students. This then goes against the requirements of the SACSSP for student assessment in the BSW. Participants reiterated that there is a gap between what the university requires in terms of fieldwork education and what the agencies are able to offer, given the limited human and material resources.

It is inevitable that students will not achieve the learning outcomes if placement requirements are vastly different from academic requirements. This difference is likely to occur with practical demands of the social workers in practice, conflicting with the requirements of the BSW programme. The question arises then whether a suitable placement is something in the idealistic mind of the academic? Will field placements always meet all the requirements of the BSW programme? What would be an acceptable compromise? These are certainly questions for further exploration as the new BSW standards are currently implemented in South African universities.

The significance of this study is that the findings can assist curriculum developers, academics, field supervisors and students to better understand the role and responsibility of the student supervisor in the context of the BSW requirements. Additionally, they will have insight into the gaps, challenges and recommendations made by stakeholders themselves, for more relevant and efficient student supervision programmes.

Universities offering the BSW degree could draw on the findings of this study to adapt it to their own contexts. The findings provide insight from an insider perspective regarding the developmental needs of social workers for postgraduate studies and continued professional development relating to supervision generally. Furthermore, the SACSSP in conjunction with higher education institutions and the social work profession can benefit from these 
research findings and recommendations, as they identify areas for possible continuous professional development of student supervisors.

There is no doubt that student supervision is a concern for immediate attention. At a time when social work supervision has been declared a "scarce skill", the DSD and the SACSSP should become major collaborators in lobbying for and allocating human and financial resources for student supervision, which should include non-governmental organisations where most BSW students are placed for fieldwork education. Monitoring of the the development of the profession (as prescribed in the SACSSP code of conduct) could then be carried out effectively. Finally, the challenges described by participants in this study infringe on the academic development of social work students. If the professionals responsible for the supervision of students do not agree, have vague ideas of the learning outcomes in the BSW, and/or have very limited knowledge of assessment practices in the BSW, then the idea of producing and retaining good quality social workers will be an illusion. 


\section{References}

Botha, N.J. (2000). Supervisie en Konsultasie in Maatskaplike Werk Stellenbosch: Druforma, Eerste Uitgawe.

Bozalek, V. (2009). "Outcomes-based Assessment: Necessary Evil or Transformative Potential?" Social Work/Maatskaplike Werk 45(1):91-110.

Bradley, G., Engelbrecht, L and Höjer, S. (2010). "Supervision: A Force for Change: Three Stories Told” International Social Work 53(6):773-790.

Butler, G. (2010). "Reflecting on Emotion in Social Work" in Knott, C. and Scragg, T. (Eds.). Reflective Practice in Social Work Glasgow: Learning Matters Ltd, First Edition, $33-47$.

Collins, C. (2012). "Transforming Teaching and Learning in South Africa: First Year in the Bachelor of Social Work Social Work Education: International Journal", http//www.tandfontline.com/loi/cswe20 (Accessed on 10/08/2016).

Creswell, J.W. (2007). Qualitative Inquiry and Research Design: Choosing from Five Approaches London: Sage Publications, Second Edition.

Creswell, J.W. (2009). Research Design: Qualitative Quantatitive and Mixed Approaches Thousand Oaks: Sage Publications, Second Edition.

De Vos, A.S. (2005). "Qualitative Data Analysis and Interpretation" in De Vos, A.S., Fouché, C.B., Delport, C.S.L. and Strydom H. (Eds.). Research at Grass Roots: For the Social Sciences and Human Service Professions Pretoria: Van Schaik Publishers, Third Edition, 333-349.

Department of Social Development (DSD) and the South African Council for Social Service Professions (SACSSP). (2012). Supervision Framework for the Social Work Profession in South Africa Pretoria: Department of Social Development.

Doel, M. and Shardlow, S. (Eds.). (1986). Social Work in a Changing World: An International Perspective on Practice Learning Aldershot: Ashgate Publishing Ltd.

Dykes, G.Z. (2009). "Recognition of Prior Learning and Support: Are the Needs of RPL First Year Students Different?” Social Work/Maatskaplike Werk 45(3):314-326.

Earl, N. (2008). "Socil work in social change: The Profession and Education of Social Workers in South Africa", www.hsrcpress.ac.za (Accessed on 26/03/2013).

Engelbrecht, L.K. (2001). Supervisie aan Studente Wellington: Lanzo. 
Engelbrecht, L.K. (2002).'n Maatskaplike Ontwikkelingsgerigte Perspektief op Supervisie aan Maatskaplike Studente by Opleidingsinstansies in Suid Afrika (Ongepubliseerde Doktorale Proefskrif) Stellenbosch: Universiteit van Stellenbosch, Departement van Maatskaplike Werk.

Engelbrecht, L. (2004). "Operationalising a Competence Model of Supervision to Empower Social Workers and Students in South Africa" Social Work/Maatskaplike Werk 40(2): 206216.

Fouché, C. and Schurink, W. (2011). "Qualitative Research Designs" in De Vos, A., Strydom, H., Fouché, C. and Delport, C. (Eds.). Research at Grass Roots Pretoria: Van Schaik, Fourth Edition, 307-327.

Guttman, E., Eisikovits, Z and Malucci, A. (1988). "Enriching Social Work Supervision from a Competence Perspective” Journal of Social Work Education 24(3): 278-288.

Hawkins, P. and Shohet, R. (2000). Supervision in the Helping Professions: Supervision in Context Columbia: Columbia Open University Press, Second Revised Edition.

Kadushin, A. (1992). Supervision in Social Work New York, Columbia University Press, Third Edition.

Kadushin, A and Harkness, D. (2002). Supervision in Social Work New York and Chichester, West Sussex: Columbia University Press, Fourth Edition.

Knight, C. (2001). "The Process of Field Instruction: BSW and MSW Students' Views of Effective Field Supervision" Journal of social work Education 37(3):357-379.

Koh, L.C. (2002). "The Perceptions of Nursing Students of Practice-based Teaching” Nurse Education Today 2(1):35-43.

Lombard, A., Grobbelaar, M. and Pruis, S. (2003). "Standards for Social Work Qualifications in South Africa" Social Work/Maatskaplike Werk 39(1):1-17.

Morgan, R. (2006). "Using Clinical Skills Laboratories to Promote Theory-Practice Integration during First Year Practical Placement: An Irish Perspective" Journal of Clinical Nursing 15(2):155-161.

Nzira, V. and Williams, P. (2008). Anti-oppressive Practice in Health and Social Care London: Sage Publications.

Oko, J. (2008). Understanding and Using Theory in Social Work London: Learning Matters. 
Petersen, S. (2010). Challenges of Integrating Theory and Practice in Social Work (Unpublished Master's Thesis) Cape Town: University of the Western Cape, Department of Social Work.

Race, P. (2005). Making Learning Happen: A Guide for Post-compulsory Education London: Sage Publications.

Ramsden, P. (2003). Learning to Teach in Higher Education London: Routledge Falmer, Third Edition.

Reyneke, R. (2010). "Social Work Values and Ethics" in Nicholas, L., Rautenbach, J. and Maistry, M. (Eds.). Introduction to Social Work Cape Town: Juta and Company, 231-246.

Schenck, C.J. (2009). "The Socio-Economic Realities of the Social Work Students of the University of South Africa” Social Work/Maatskaplike Werk 45(3):299-313.

Shardlow, S. and Doel, M. (1996). Practice Learning and Teaching London: British Association of Social Workers.

Simpson, B. and Raniga, T. (2014). "Student Supervision" in Engelbrecht, L. (Ed.). Management and Supervision of Social Workers Hampshire: Cengage Learning.

South African Council for Social Services Professions (SACSSP). (2003). "Policy Guidelines for Course of Conduct, Code of Ethics and the Rules for Social Workers", http://www.sacssp.co.za (Accessed on 31/o3/2010).

South African Qualifications Authority (SAQA). (2003). "Qualification: Bachelor of Social Work Government Gazette Vol. 452 No. 24362 of 7 February 2003", http://www.saqa.org.za/nsb/sgestds/assessors2.html (Accessed on 21/02/2008).

Spouse, J. (2001). "Bridging Theory and Practice in the Supervisory Relationship" Journal of Advanced Nursing 33(4):512-522.

Teigiser, K. (2009). “Field Note: New Approaches for Generalist Field Education” Journal of Social Work Education 45(3):139-145.

Walker, J., Crawford, K. and Parker, J. (2008). Practice Education in Social Work: A Handbook for Practice Teachers, Assessors and Educators Great Britain, Exeter: Learning Matters.

Weimer, M. (2002). Learner-centered Teaching: Five Key Changes to Practice San Francisco: Jossey-Bass. 
Yin, R.K. (2003). Case Study Research Design and Methods Thousand Oaks: Sage Publications. 